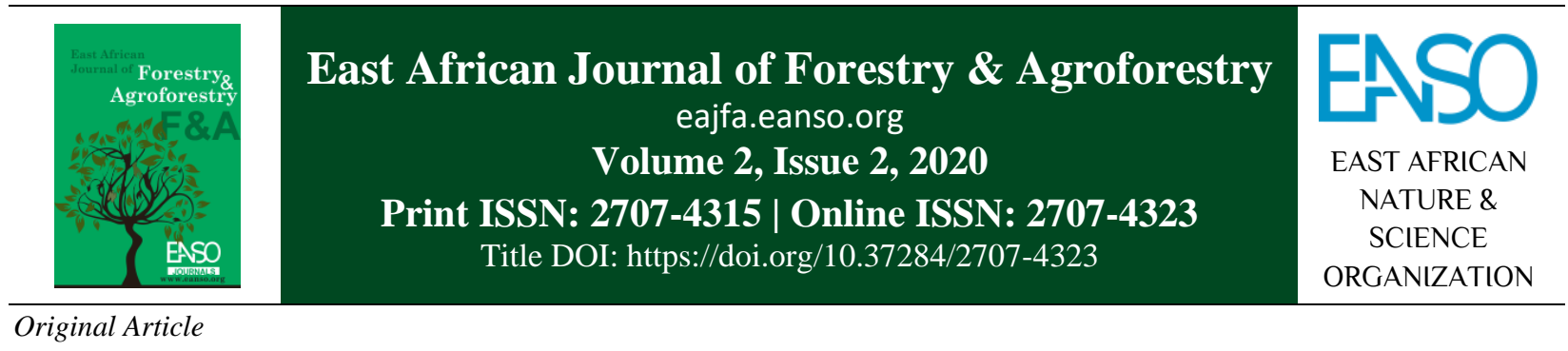

\title{
Forest Tree Composition: A Comparative Study of Timber Species in Bayelsa State Nigeria
}

\author{
Samuel Olatokunbo Ihinmikaiye ${ }^{*}$, Bernard Edache Ochekwu ${ }^{2}$, Josiah Muonam Ikuli ${ }^{3}$, \\ Doris Akinjagunla Atinuke ${ }^{2}$ \& Abel Zikenal Keresinbofa ${ }^{4}$ \\ ${ }^{1}$ Department of Biology, Federal University Otuoke, Nigeria. \\ ${ }^{2}$ Department of Plant Science and Biotechnology, University of Port Harcourt, Nigeria. \\ ${ }^{3}$ Department of Crop and Soil Science, Niger Delta University, Bayelsa State, Nigeria. \\ ${ }^{4}$ Department of Forestry, Bayelsa State Ministry of Environment, Nigeria. \\ * ORCID: https://orcid.org/0000-0001-9793-6224; Author for Correspondence email: ihinmikaiye.samuel@yahoo.com.
}

Article DOI: https://doi.org/10.37284/eajfa.2.2.258

\section{Article history: ABSTRACT}

30 December 2020 Measuring tree species diversity is critical for forest management, particularly where timber species suffer undue anthropogenic pressure. This study was

Keywords: carried out in Bayelsa State, Nigeria. A sample plot was systematically chosen from randomly selected communities in each of the three senatorial districts

Forest, Bayelsa West (BW), Bayelsa East (BE) and Bayelsa Central (BC) of the State.

Timber, Each sample plots measured $25 \mathrm{~m}$ x $25 \mathrm{~m}$ and all timber tree species that were

Diversity,

Conservation, at least six feet above ground level within each sample plot were identified, Bayelsa State. counted and measured. Fifty individual timbers were encountered in the sample plot at Ogobiri community in BW, fifty-two at Kolo 1 community in BE and fifty-six at Gbarain community in BC belonged to 18, 16 and 14 different families respectively. Families with the largest number of species in the plots were Gentianaceae and Meliaceae, and the highest diversity indices were recorded from BE senatorial district. Generally, the basal area of the sample plots increases with an increase in diameter at breast height. The forested zones were on flat terrain characterized by seasonal flood inundation, and the similarities of timber species in the plots occurred as (BW-BC)> (BW-BE)> (BC-BE). Also, four tree species Coelocaryon preussii, Sacoglottis gabonensis, Milicia excelsa and Triplochiton scleroxylon were identified as rare species, and management options that would ensure ad infinitum supply of timber species were proposed. 


\section{APA CITATION}

Ihinmikaiye, S. O., Ochekwu, B. E., Ikuli, J. M., Atinuke, D. A., \& Keresinbofa, A. Z. (2020). Forest Tree Composition: A Comparative Study of Timber Species in Bayelsa State Nigeria. East African Journal of Forestry and Agroforestry, 2(2), 6473. https://doi.org/10.37284/eajfa.2.2.258

\section{CHICAGO CITATION}

Ihinmikaiye, Samuel Olatokunbo, Bernard Edache Ochekwu, Josiah Muonam Ikuli, Doris Akinjagunla Atinuke, and Abel Zikenal Keresinbofa. 2020. "Forest Tree Composition: A Comparative Study of Timber Species in Bayelsa State Nigeria". East African Journal of Forestry and Agroforestry 2 (2), 64-73. https://doi.org/10.37284/eajfa.2.2.258.

\section{HARVARD CITATION}

Ihinmikaiye, S. O., Ochekwu, B. E., Ikuli, J. M., Atinuke, D. A., and Keresinbofa, A. Z. (2020) "Forest Tree Composition: A Comparative Study of Timber Species in Bayelsa State Nigeria", East African Journal of Forestry and Agroforestry, 2(2), pp. 64-73. doi: 10.37284/eajfa.2.2.258.

\section{IEEE CITATION}

S. O. Ihinmikaiye, B. E. Ochekwu, J. M. Ikuli, D. A. Atinuke, and A. Z. Keresinbofa, "Forest Tree Composition: A Comparative Study of Timber Species in Bayelsa State Nigeria”, EAJFA, vol. 2, no. 2, pp. 64-73, Dec. 2020.

\section{MLA CITATION}

Ihinmikaiye, Samuel Olatokunbo, Bernard Edache Ochekwu, Josiah Muonam Ikuli, Doris Akinjagunla Atinuke, and Abel Zikenal Keresinbofa. "Forest Tree Composition: A Comparative Study of Timber Species in Bayelsa State Nigeria". East African Journal of Forestry and Agroforestry, Vol. 2, no. 2, Dec. 2020, pp. 64-73, doi:10.37284/eajfa.2.2.258.

\section{INTRODUCTION}

Trees are an important constituent of terrestrial life. They exist in the major terrestrial biomes of the world and are the most conspicuous species in the forest estate upon which humanity depends for variety of services (Aigbe \& Omokhua, 2015; MEA, 2005). The tropical forest is one of the principal vegetation types of the globe (Whitmore, 1998); they are a reservoir of densely packed trees, which their diversity is fundamental to the total rainforest biodiversity (Ihinmikaiye \& Unanaonwi, 2018). They are essential for human survival, economic wellbeing, ecosystem function and stability (Singh, 2002). According to Cunningham and Lindenmaye (2005) timber account for over half of global wood consumption, an underlying reason behind the clearing of about $90 \%$ of natural vegetation and the loss of a considerable number of flora and fauna annually in developing countries (Ossai, 2018).

Although West Africa possesses an enormous diversity of forest trees, extending over the major part of the zone. Aigbe et al. (2015) observed that anthropogenic pressure puts forest trees in West Africa under severe threat. The rate of timber species loss in the region is in stark contrast to those of other tropical regions of the world (FAO, 2012; Okonkwo et al., 2012). Forest canopy structure provides a good indicator for predicting the ecological soundness and susceptibility of forests to rapid degradation (Magurran, 1988). Okuda et al. (2003) asserted that the canopy structure of a forest is determined by the tree species present in the forest, and the loss alters the abundance of timber trees within a forest zone.

Forest communities in Nigeria especially in the Niger Delta region have suffered severe biological diversity loss at both local and regional scales for decades. Currently, in Bayelsa State, there is a massive onslaught of timber trees (Ihinmikaiye \& Unanaonwi, 2018). Although the State appears to be rich in tree species, logging activities and timber processing focus only on a limited number of species in demand. The conversion of forest land to agriculture militate with the maintenance of pristine forest, biodiversity and ecosystem function (Suratman, 2012; Mwakalukwa et al., 2014).

A critical gauge for determining the level of tree species diversity, as well as biodiversity conservation, involves measuring of tree species diversity within the forest estate of a region (Magurran, 2004). Hence, forest inventory that involves a systematic sampling design was conducted in the Senatorial districts of the State. This study determines the forest timber composition, similarity level and identifies the tree florae within sampled plots. Management options 
that would guarantee constant supply with a focus on tree species conservation were proposed.

\section{METHODOLOGY}

\section{Study Area}

The study was carried out in the lowland forest zones within Bayelsa State between January 2019 and March 2020. Bayelsa is one of the six states that constitute the South-South geopolitical zones of Nigeria. It is constitutionally delineated into three senatorial districts.

A forest site was randomly selected from a community in each of the districts, namely: Ogobiri community in Bayelsa West (BW) Senatorial district; Gbarain community in Bayelsa Central (BC) Senatorial district and Kolo 1 community in Bayelsa East (BE) Senatorial district. Geographically, the sites are within latitudes $4^{\circ} 50^{\prime} \mathrm{N}$ and $5^{\circ} 05^{\prime} \mathrm{N}$ and longitude $6^{\circ} 10^{\prime} \mathrm{E}$ and $6^{\circ} 40^{\prime} \mathrm{E}$ (Oborie \& Nwankwoala, 2017). The temperature ranges between $26{ }^{\circ} \mathrm{C}$ to $31{ }^{\circ} \mathrm{C}$ with high relative humidity depending on the season of the year, high rainfall occurs between April and November, and dry season with sparse rainfall occurs between December and March yearly. The soil consists of sedimentary alluvium and abandoned beach ridges, formed in the early Holocene (Akpokodje, 1989). Physiographically, the soil types vary yet imbued with nutrients that support biological diversity and arable crop production (Diri \& Joseph, 2020).

\section{Data Collection and Analysis}

Three sample plots were selected by simple random sampling technique. Each of the plots measured 25 $\mathrm{m}$ by $25 \mathrm{~m}$ in length and all timber tree species that were 6 feet above ground level within each sample plot were counted, identified by their botanical and family names, and were measured at diameter at breast height (dbh $\geq 4.5$ feet) after Hall et al. (2003). A d-tape calibrated in centimetres was used to determine the diameter of the timber trees. Specimens of the trees (such as fruits, flowers and twiglets) that could not be identified immediately were collected for proper identification at the University Herbarium, Federal University Otuoke, Nigeria.

\section{Determination of Species Diversity in the Sampling Plots}

Diversity indices have been used to gauge the quality of forest community structure because they are considered ecological indicators (Kerkhoff, 2010). Thus, the tree species diversity was determined using the Simpson index (C), ShannonWiener index of diversity $(\mathrm{H})$, Pileou's index of evenness (E), Margalef's index (d) and Menhinick's index (D).

Simpson index $(\mathbf{C})=\sum_{i=1}^{S} \mathrm{Pi}^{2}$

$\mathrm{Pi}$ is the proportion of individuals of the $i$ th species. Where, $\mathrm{Pi}=\mathrm{n} i / \mathrm{N}, \mathrm{n} i=$ number of individuals of the ith species in the plot; $\mathrm{N}=$ total number of individuals in the plot; $S=$ number of species in the plot; The value of ' $C$ ' range between 0 and 1.1 represents infinite diversity and 0 , no diversity.

Shannon-Wiener index $(\mathbf{H})=-\mathrm{Pi}(\log \mathrm{P} i)$

Where, $\mathrm{P} i$ is the same as Simpson's index.

Pileou's index of evenness $(\mathbf{E})=\mathrm{H} / \mathrm{M}_{\max }=\mathrm{H} / \log \mathrm{S}$

Where $\mathrm{H}=$ Shannon Wiener index and, $\mathrm{S}=$ total number of species recorded. Evenness assumes a value between 0 and 1, 1 being complete evenness.

Margalef's index (D) $=\mathrm{S}-1 / \log \mathrm{N}$

Where $\mathrm{S}=$ total number of species and $\mathrm{N}=$ total number of individuals in the plot.

Menhinick index $(\mathbf{d})=\mathrm{S} / \sqrt{ } N$

Where, $\mathrm{S}$ and $\mathrm{N}$ are the same as in Margalef's. Margalef and Menhinick indices are used to calculate species richness.

\section{Similarity Measures in the Occurrences of the Identified Tree Species in the Sampling Plots}

Similarity measures in the occurrence of the species in the sampling plots were determined using:

1. Index of Similarity (IS)

$\mathrm{IS}=2 \mathrm{C} \times 100 /(\mathrm{A}+\mathrm{B})$ 
2. Jaccard Index (SJ)

$$
\mathrm{SJ}=\mathrm{C} /(\mathrm{A}+\mathrm{B}+\mathrm{C})
$$

3. Sorenson-Dice Index $\left(\mathrm{S}_{\mathrm{SD}}\right)$

$$
\mathrm{SSD}=2 \mathrm{C} /(\mathrm{A}+\mathrm{B}+2 \mathrm{C})
$$

4 Ochoi Index (SO)

$$
\mathrm{SO}=\mathrm{C} / \sqrt{ }(\mathrm{A}+\mathrm{C})+\sqrt{ }(\mathrm{B}+\mathrm{C})
$$

5. Asymmetrical Similarity $\left(\mathrm{S}_{\mathrm{AS}}\right)$

$$
\mathrm{S}_{\mathrm{AS}}=\mathrm{B} /(\mathrm{B}+2 \mathrm{C})
$$

Where $\mathrm{A}$ is the number of species in the first zone; $\mathrm{B}$ is the number of species in the second zone, and $\mathrm{C}$ is the number of species common to both first and second zones.

\section{Estimation of Basal Area and Relative density}

The basal area of each tree was computed using the equation $\mathrm{BA}=\pi \mathrm{D}^{2} / 4$, where $\mathrm{D}=\mathrm{dbh}(\mathrm{m})$. The basal area of each plot was estimated by summing the BA of all individual trees within the sampling plots.

Relative Density (\%) of each species was computed as follows: $\mathrm{RD}=(n / N) \times 100 \%$, where $\mathrm{RD}$ is the relative density of the species; $n$ is the number of individual tree species and $N$ is the total number of trees sampled per plot.

\section{Identification of the Rare Species in the Study}

The sample plots were considered as representative of the forest estate in the districts. Thus, tree species that are singleton (i.e., species represented by only one stand and peculiar to a sample plot) are considered rare. The indigenous knowledge on the identified rare species was determined and used to propose conservation strategies that would ensure the protection of the species.

\section{RESULTS}

The relative density, size and timber species diversity of trees encountered in the three sample plots are presented in Table 1, 2 and 3. Families with a large number of species in the plots include Gentianaceae (with three species encountered in the sampling plot at Kolo 1 of Bayelsa East (BE)), Meliaceae (with three species encountered at Ogobiri community in Bayelsa West (BW), as well as in Bayelsa East (BE)). Table 1 shows that $A$. djalonensis and E. guineensis had the highest number of individual tree species (4) and relative density (RD). While seven timber species ( $C$. procera, C. preussii, G. brevis, P. Oleosa, $P$. angolensis, $S$. gabonensis and M. stipulosa) were identified in the sample plot at Kolo 1 (BE) as singletons with low relative density.

Table 1: Relative Frequency, Sizes and Tree Diversity of the Sample Plot in Kolo 1 Community of Bayelsa East

\begin{tabular}{llllll}
\hline Tree Species & Family & No. of sp. & RD & Mdbh & TBA/sp \\
\hline Alstonia boonei & Apocynaceae & 3 & 5.77 & 24.33 & 0.16 \\
Anthocleista djalonensis & Gentianaceae & 4 & 7.69 & 28.29 & 0.29 \\
Anthocleista vogelii & Gentianaceae & 2 & 3.85 & 17.4 & 0.05 \\
Berlinia grandiflora & Fabaceae & 2 & 3.85 & 32.5 & 0.20 \\
Carapa procera & Meliaceae & 1 & 1.92 & 25.20 & 0.05 \\
Ceiba pentandra & Malvaceae & 3 & 5.77 & 23.07 & 0.16 \\
Coelocaryon preussii & Myristicaceae & 1 & 1.92 & 38.00 & 0.11 \\
Cynometra vogelii & Gentianaceae & 2 & 3.85 & 33.00 & 0.19 \\
Elaeis guineensis & Arecaceae & 4 & 7.69 & 43.43 & 0.69 \\
Ficus capensis & Moraceae & 2 & 3.84 & 27.2 & 0.13 \\
Glyphaea brevis & Malvaceae & 1 & 1.72 & 16.1 & 0.02 \\
Irvingia gabonensis & Irvingeaceae & 3 & 5.77 & 36.67 & 0.35 \\
Khaya ivorensis & Meliaceae & 2 & 3.84 & 30.65 & 0.17 \\
Lophira alata & Ochnaceae & 2 & 3.85 & 43.00 & 0.29 \\
Mitragyna stipulosa & Rubiaceae & 1 & 1.92 & 8.2 & 0.01 \\
\hline
\end{tabular}


East African Journal of Forestry and Agroforestry, Volume 2, Issue 2, 2020

Article DOI: https://doi.org/10.37284/eajfa.2.2.258

\begin{tabular}{llllll}
\hline Tree Species & Family & No. of sp. & RD & Mdbh & TBA/sp \\
\hline Musanga cecropioides & Urticaceae & 3 & 5.76 & 33.4 & 0.32 \\
Nauclea diderrichii & Rubiaceae & 2 & 3.84 & 8.4 & 0.01 \\
Panda oleosa & Pandaceae & 1 & 1.92 & 46.3 & 0.17 \\
Pycnanthus angolensis & Myristicaceae & 1 & 1.92 & 45.6 & 0.16 \\
Raphia hookeri & Arecaceae & 2 & 3.85 & 39.5 & 0.25 \\
Sacoglottis gabonensis & Humiriaceae & 1 & 1.92 & 45.20 & 0.16 \\
Spondias mombins & Anacardiaceae & 3 & 5.77 & 24.17 & 0.16 \\
Treculia africana & Moraceae & 3 & 5.77 & 33.83 & 0.31 \\
Vitex grandifolia & Lamiaceae & 3 & 5.77 & 14.63 & 0.06 \\
\hline
\end{tabular}

T. africana had the highest number of individual timber species (4) in the sample plot at Ogobiri community of BW (Table 2); while M. excelsa, C. englerianus, M. stipulosa and L. alata had one individual each in the sample plot with corresponding low relative density.

Table 2: Relative Frequency, Sizes and Tree Diversity of the Sample Plot in Ogobiri Community of Bayelsa West

\begin{tabular}{llllll}
\hline Tree Species & Family & No. of sp. & RD & Mdbh & TBA/sp. \\
\hline Alstonia boonei & Apocynaceae & 3 & 6 & 16.67 & 0.09 \\
Berlinia grandiflora & Fabaceae & 2 & 4 & 22.15 & 0.08 \\
Brilinia stenocarpa & Phyllanthaceae & 2 & 4 & 36.55 & 0.22 \\
Carapa procera & Meliaceae & 2 & 4 & 29.35 & 0.16 \\
Ceiba pentandra & Malvaceae & 2 & 4 & 15.67 & 0.05 \\
Cynometra vogelii & Gentianaceae & 3 & 6 & 8.130 & 0.02 \\
Ctenolophone englerianus & Ctenolophonceae & 1 & 2 & 34.80 & 0.10 \\
Elaeis guineensis & Arecaceae & 3 & 6 & 39.17 & 0.43 \\
Ficus capensis & Moraceae & 2 & 4 & 15.70 & 0.04 \\
Irvingia gabonensis & Irvingeaceae & 2 & 4 & 21.90 & 0.10 \\
Khaya ivorensis & Meliaceae & 3 & 6 & 16.83 & 0.07 \\
Lophira alata & Ochnaceae & 1 & 2 & 33.10 & 0.09 \\
Mammea africana & Clusiaceae & 2 & 4 & 31.30 & 0.17 \\
Milicia excelsa & Moraceae & 1 & 2 & 23.40 & 0.43 \\
Mitragyna stipulosa & Rubiaceae & 1 & 2 & 10.20 & 0.01 \\
Musanga cecropioides & Urticaceae & 2 & 4 & 8.85 & 0.01 \\
Panda oleosa & Pandaceae & 3 & 6 & 18.93 & 0.09 \\
Pycnanthus angolensis & Myristicaceae & 2 & 4 & 19.00 & 0.06 \\
Spondias mombins & Anacardiaceae & 2 & 4 & 24.95 & 0.11 \\
Synsepalum stipulatum & Sapotaceae & 2 & 4 & 15.80 & 0.04 \\
Tetrapleura tetraptera & Fabaceae & 2 & 4 & 12.05 & 0.03 \\
Treculia africana & Moraceae & 4 & 8 & 30.20 & 0.32 \\
Uapaca heudelotii & Phyllanthaceae & 3 & 6 & 25.37 & 0.16 \\
\hline
\end{tabular}

U. heudelotii had the highest RD and number of individual species in the sample plot at Gbarain community of Bayelsa Central (BC) (Table 3); whereas, $N$. diderrichii and T. scleroxylon had one individual each in the sample plot. 
East African Journal of Forestry and Agroforestry, Volume 2, Issue 2, 2020

Article DOI: https://doi.org/10.37284/eajfa.2.2.258

Table 3: Relative frequency, sizes and tree diversity of the sample plot in Bayelsa Central

\begin{tabular}{llllll}
\hline Tree Species & Family & No. of sp. & RD & Mdbh & TBA/sp \\
\hline Alstonia boonei & Apocynaceae & 4 & 7.14 & 23.00 & 0.18 \\
Anthocleista vogelii & Gentianaceae & 2 & 3.57 & 21.45 & 0.07 \\
Anthostema aubryanum & Euphorbiaceae & 3 & 5.36 & 18.47 & 0.12 \\
Cleistopholis patens & Annonaceae & 2 & 3.57 & 21.65 & 0.09 \\
Ctenolophone englerianus & Ctenolophonceae & 3 & 5.36 & 27.2 & 0.22 \\
Elaeis guineensis & Arecaceae & 4 & 7.14 & 9.38 & 0.03 \\
Erythrophleum ivorense & Fabaceae & 3 & 5.36 & 35.4 & 0.42 \\
Ficus capensis & Moraceae & 2 & 3.57 & 31.45 & 0.17 \\
Ficus exasperata & Moraceae & 4 & 7.14 & 19.3 & 0.13 \\
Garcinia mannii & Clusiaceae & 2 & 3.57 & 23.7 & 0.11 \\
Irvingia gabonensis & Irvingeaceae & 3 & 5.36 & 28.73 & 0.25 \\
Khaya ivorensis & Meliaceae & 3 & 5.36 & 17.93 & 0.09 \\
Mammea africana & Clusiaceae & 3 & 5.36 & 25.47 & 0.21 \\
Musanga cecropioides & Urticaceae & 3 & 5.36 & 11.00 & 0.03 \\
Nauclea diderrichii & Rubiaceae & 1 & 1.79 & 53.40 & 0.22 \\
Raphia hookeri & Arecaceae & 3 & 5.36 & 14.07 & 0.05 \\
Tetrapleura tetraptera & Fabaceae & 2 & 3.57 & 22.55 & 0.10 \\
Treculia africana & Moraceae & 3 & 5.36 & 31.00 & 0.25 \\
Triplochiton scleroxylon & Sterculiaceae & 1 & 1.79 & 11.90 & 0.01 \\
Uapaca heudelotii & Phyllanthaceae & 5 & 8.92 & 17.24 & 0.15 \\
\hline
\end{tabular}

Field observation revealed that six of the timber species (A. boonei, E. guineensis, I. gabonensis, $K$. ivorensis, M. cecropioides and T. africana) were common to the three sampling plots. While $A$. djalonensis, C. preussii, G. brevis, S. gabonensis, and $V$. grandiflora were peculiar to the sample plot at Kolo 1 community of BE; B. stenocarpa, $M$. excelsa, and $S$. stipulatum were peculiar to the sample plot at Ogobiri community of BW; and $A$. aubryanum, C. patens, G. mannii, K. ivorensis and $X$. staudtii were peculiar to the sampling plot at
Gbarain community in $\mathrm{BC}$. The total number of timber species encountered per sampling plot is presented in Table 4. Fifty individual timber species were encountered in the sample plot at Ogobiri community (BW), fifty-two in Kolo 1 community (BE) and fifty-six in Gbarain community (BC), the species belonged to 18,16 and 14 different families respectively. The Table also reveals the level of timber species diversity indices in the sampling plots.

Table 4: Biodiversity indices of the tree species in the three sampling plots

\begin{tabular}{llll}
\hline Diversity indice & BW & BC & BE \\
\hline C & 0.470 & 0.723 & 1.04 \\
$\mathrm{H}$ & 3.033 & 2.931 & 3.081 \\
$\mathrm{E}$ & 0.060 & 0.052 & 0.059 \\
$\mathrm{D}$ & 5.624 & 4.720 & 5.821 \\
$\mathrm{~d}$ & 3.253 & 2.673 & 3.328 \\
No. of individual & 50 & 56 & 52 \\
No. of species & 23 & 20 & 24 \\
No. of family & 18 & 14 & 16 \\
\hline
\end{tabular}

Key: $\boldsymbol{C}=$ Simpson, $H=$ Shannon-Wiener, $E=$ Evenness, $D=$ Margalef, $\boldsymbol{d}=$ Menhinick 
Although the timber species diversity varies reasonably yet, the highest Simpson (C), ShannonWiener (H), Evenness (E), Margalef (D) and Menhinick (d) values occurred in the sample plot at BE. Whereas, the highest values of the individual number of trees present (56), and species with the highest number of family (18) occurred in BC and BW sample plots respectively. Table 5 shows the timber species growth variables. The Basal area (Ba) increases with an increase in diameter at breast height (dbh). The highest values of $\mathrm{Ba}$ and $\mathrm{dbh}$ occurred in the sample plot at Kolo 1 in BE, while the least $\mathrm{Ba}$ was recorded in Ogobiri community in $\mathrm{BW}$. The Field observation revealed that the sample plots were located in flat terrain characterized by seasonal flood inundation.

Table 5: Species Growth Variables and Land's Surface Feature

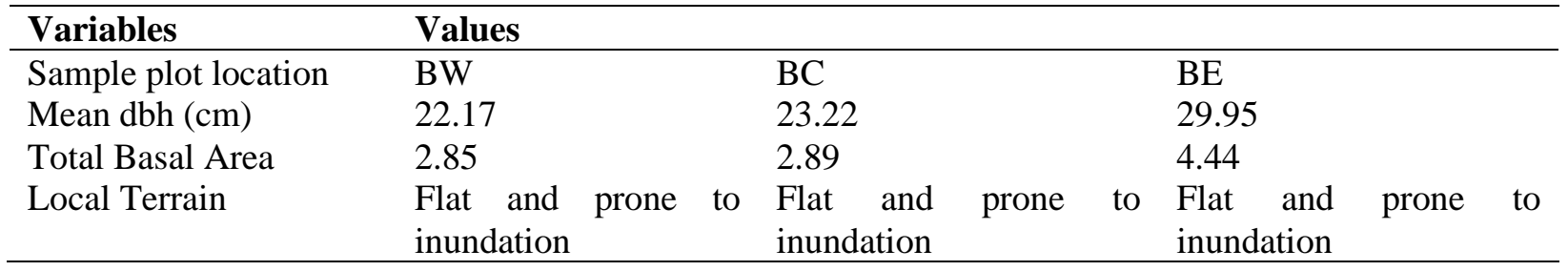

The species encountered in the sample plots were quite similar to one another (Table 6), the level of similarities of the species in the three sampling plots is represented as $(\mathrm{BW}-\mathrm{BC})>(\mathrm{BW}-\mathrm{BE})>$ (BC-BE).

Table 6: Similarity Measures on the Occurrence of Tree Species in the Three Sampling Plots of the Study Area

\begin{tabular}{llll}
\hline Similarity Indices & BW-BC & BW-BE & BC-BE \\
\hline IS $(\%)$ & 59.58 & 46.51 & 45.46 \\
$\mathrm{~S}_{\mathrm{SD}}$ & 0.37 & 0.32 & 0.31 \\
$\mathrm{~S}_{\mathrm{J}}$ & 0.23 & 0.19 & 0.19 \\
$\mathrm{~S}_{\mathrm{AS}}$ & 0.51 & 0.51 & 0.50 \\
$\mathrm{~S}_{\mathrm{O}}$ & 1.14 & 0.89 & 0.89 \\
\hline
\end{tabular}

Four indigenous tree species were identified as rare timber species in the sample plots (Table 7) and the Table provides conservation inference on the species: though the species are some of the choice trees with high market values in the State.

Table 7: Conservation Inference on the Rare Species

\begin{tabular}{|c|c|c|c|c|c|}
\hline \multirow{2}{*}{$\begin{array}{l}\text { Confirmed } \\
\text { rare species }\end{array}$} & \multicolumn{5}{|c|}{ Ecological knowledge } \\
\hline & Ecology & Propagation & Utility & Habit & Conservation inference \\
\hline $\begin{array}{l}\text { Coelocaryon } \\
\text { preussii }\end{array}$ & $\begin{array}{l}\text { Rainforest } \\
\text { /swamp } \\
\text { tree }\end{array}$ & $\begin{array}{l}\text { Seeds, } \\
\text { wildlings }\end{array}$ & $\begin{array}{l}\text { timber, } \\
\text { carpentry } \\
\text { furniture, } \\
\text { building, } \\
\text { carving }\end{array}$ & Tree & $\begin{array}{l}\text { Locals are quite familiar with the trees; } \\
\text { however, an enlightenment campaign on the } \\
\text { importance of trees that necessitates tree } \\
\text { cultivation by the aboriginals is required. }\end{array}$ \\
\hline $\begin{array}{l}\text { Sacoglottis } \\
\text { gabonensis }\end{array}$ & $\begin{array}{l}\text { Rainforest } \\
\text {, swamp }\end{array}$ & $\begin{array}{l}\text { Seeds, } \\
\text { wildlings }\end{array}$ & $\begin{array}{l}\text { timber, } \\
\text { furniture, } \\
\text { building, } \\
\text { carving }\end{array}$ & $"$ & $\begin{array}{l}\text { The swamp forest vegetation of the study area } \\
\text { will support the cultivation of this rare species }\end{array}$ \\
\hline
\end{tabular}




\begin{tabular}{|c|c|c|c|c|c|}
\hline \multirow{2}{*}{$\begin{array}{l}\text { Confirmed } \\
\text { rare species }\end{array}$} & \multicolumn{5}{|c|}{ Ecological knowledge } \\
\hline & Ecology & Propagation & Utility & Habit & Conservation inference \\
\hline $\begin{array}{l}\text { Milicia } \\
\text { excelsa }\end{array}$ & Rainforest & $\begin{array}{l}\text { Seeds, } \\
\text { wildlings }\end{array}$ & $\begin{array}{l}\text { timber, } \\
\text { furniture, } \\
\text { building, } \\
\text { carving }\end{array}$ & $"$ & $\begin{array}{l}\text { Investment in the species will meet future } \\
\text { needs of the indigenous people and provide } \\
\text { valuable economic returns. Planting of the } \\
\text { species is a way of preserving them, and this } \\
\text { will provide the rural dwellers themselves } \\
\text { sufficient use indefinitely. }\end{array}$ \\
\hline $\begin{array}{l}\text { Triplochiton } \\
\text { scleroxylon }\end{array}$ & Rainforest & $\begin{array}{l}\text { Seeds, } \\
\text { wildlings }\end{array}$ & $\begin{array}{l}\text { timber, } \\
\text { carving } \\
\text { medicine } \\
\text {, storage }\end{array}$ & $"$ & $\begin{array}{l}\text { Locals are familiar with the trees hence } \\
\text { enlightenment campaign on the conservation of } \\
\text { the species by the natives is required. The } \\
\text { aborigines' familiarity with seeds propagation } \\
\text { could be exploited through the provision of } \\
\text { seeds and or seedlings of the species }\end{array}$ \\
\hline
\end{tabular}

\section{DISCUSSION}

Lowland forests with flat terrain are prone to flood inundations, with its attendant impacts on flood intolerant tree species. The values of timber species obtained from the sample plots signify that the plots are well stocked and rich in timber species, but the majority of the timber species encountered are immature. Most of the timber species were common to the three sample plots, and typified post extraction secondary forest trees of lowland forest. The mean diameter at breast high (dbh) and Total Basal area (TBa) of the species in Bayelsa West (BW) and Bayelsa Central (BC) are relatively low compare to Bayelsa East (BE) with a greater number of closely packed species. This finding is inconsonant with Ihinmikaiye \& Unanaonwi (2018) who asserted that the level of standing stock indicates the degree of resilience and/or the extent of forest perturbation, and the magnitude of disturbance to a forest community determines its content of tree species diversity.

Evenness (E) value close to 1 indicates less variation among timber species of compared sites (Rosenzweig, 1995). Thus, low E values obtained imply a degree of dissimilarity of timber species population across the three plots; however, the diversity index gives credence to the density and richness of timber species in the plots. The sample plot at BE was the most diverse in terms of timber species, this is because the level of timber species richness in the plot is impressively large compare to those of BW and BC. The slight variation observed in the similarity indices, confirmed a shift in the level of the timber species diversity, affirming that logging activities directly influence forest structure and timber composition (Reich et al., 2001; Adekunle et al., 2013).

Conservation of rare timber species are best observed by keeping their native habitat healthy (FAO, 2018). The confirmed rare species identified in the sample plot were choice trees; this alludes to the market value and the high level of the species usefulness. The more the utility worth of a species, the susceptible it becomes to logging and the faster it declines in the wild. Logging of peculiar tree species creates sparse distribution and affects the overall structure of a forest zone. Previous findings of Lindenmayer et al. (2000); Hall et al. (2003) and Bieri (2011) revealed that exhaustive selective logging reduces the abundant status of choice forest species, sometimes up to the point of local extinction.

The rate of depletion of existing forest in Bayelsa State is a cause of concern, a focus that reduces the present and future options for using forests (FAO, 2016). Therefore, an effective and integrated approach for the conservation of both rare species and indigenous tree in general is inferred. And these must consider the documentation of individual taxa, provision of effective and protective legislation, preservation of populations in the wild as well as in cultivation, and education of the general public. Besides, it may become necessary to propagate these plants $e x$-situ and replant the seedlings back into their natural habitats 


\section{REFERENCES}

Adekunle, V. A. J., Olagoke, A. O., \& Ogundare, L. F. (2013). Timber Exploitation Rate in Tropical Rainforest ecosystem of Southwest Nigeria and its Implications on Sustainable Forest Management. Applied Ecology and Environmental Research, 11(1), 123-136.

Aigbe, H. I, Akindele, S. O., \& Onyekwelu, J. C. (2015). Tree species diversity and density pattern in Afi River Forest Reserve, Nigeria. International Journal. of Scientific \& Technology. Research. 3 (10), 178-185.

Aigbe, H. I., \& Omokhua, G. E. (2015). Tree species composition and diversity in Oban Forest Reserve, Nigeria. Journal of Agricultural Studies, 3(1), 10-24.

Akpokodje, E.G. (1989). Preliminary studies on the geotechnical characteristics of the Niger Delta subsoil. Engineering Geology, 26 (3), 247 - 257.

Cunningham, R. B., \& Lindenmayer, D. B., (2005). Modeling count data of rare species: some statistical issues. Ecology 86 (5), 1135-1142.

FAO. (2012). Forestry Resource Assessment and the State of world's Forest. Rome, Italy: FAO.

FAO. (2016). 2015 Global forest products fact and figures. Rome, Italy: FAO.

FAO. (2018). Manual of forest inventory. Forestry paper 27. Rome, Italy: FAO.

Hall, J. S., Harris, D. J., Medjibe, V., \& Ashton, P. M. S. (2003). The effects of selective logging on forest structure and tree species composition in a central African Forest: implications for management of conservation areas. Forest Ecology. and management, 183 (1-3), 249-264

Ihinmikaiye, S. O. \& Unanaonwi, O. E., (2018). Trees Species Structure and Diversity in the Lowland- Rain Forest Zone of Bayelsa State. Journal of Ecology and Natural Resources. 2 (2): 126.

Kerkhoff, A. (2010). Measuring biodiversity of ecological communities. Ecology Lab, Biology 229, Kenyon College.
Diri, K. H. \& Joseph, T. O., (2020). Assessing the macronutrient Status Some Selected Soils in Bayelsa State, South-South Nigeria. Advance Journal of Graduate Research, 8(1),105-114.

Lindenmayer, D.B., Margules, C.R. \& Botkin, D.B. (2000). Indicators of biodiversity for ecologically sustainable forest management. Conservation Biology, 14 (4), 941-950.

Magurran, A. E. (1988). Ecological diversity and its measurement. Princeton University Press.

Bieri, M. (2011). The impact of FSC certification on timber tree regeneration and floristic composition in Honduran community forests. University of Helsinki, Finland

Millennium Ecosystem Assessment (MEA). (2005). Ecosystems and human well-being. Synthesis. Washington, DC: Island Press.

Mugarran, A. E. (2004). Measuring Biological Diversity., (Blackwell: Malden, MA.).

Mwakalukwa, E. E., Meilby, H., \&Treue, T. (2014). Floristic composition, structure, and species associations of dry Miombo woodland in Tanzania. International Scholarly research notices, 2014.

Oborie, E. \& Nwankwoala, H. O. (2017). Determination of groundwater flow direction in Yenagoa, Bayelsa State, Nigeria. Journal of Scientific Achievements. 2(9), 23-27.

Okonkwo, M. C., Umar, G. A., \& Nwafor, O. E. (2002, November). Forest resources depletion and the national economy. In Proceedings of the 28th annual conference of the Forestry association in Nigeria, FRIN, Ibadan, pp. 94100.

Okuda, T., Suzuki, M., Adachi, N., Quah, E. S., Hussein, N. A., \&Manokaran, N. (2003). Effect of selective logging on canopy and stand structure and tree species composition in a lowland dipterocarp forest in peninsular Malaysia. Forest ecology and management, 175(1-3), 297-320.

Ossai, O. A. (2018). Taxonomic Rambling of Flora Diversity in Olokemeji Forest Reserve, Nigeria. 
In Proceedings of 6th NSCB Biodiversity Conference; Uniuyo (Vol. 245, p. 249).

Reich, P. B., Bakken, P., Carlson, D., Frelich, L. E., Friedman, S. K., \&Grigal, D. F. (2001). Influence of logging, fire, and forest type on biodiversity and productivity in southern boreal forests. Ecology, 82(10), 2731-2748.

Rosenzweig, M. L. (1995). Species diversity in space and time. Cambridge University Press

Singh, J. S. (2002). The biodiversity crisis: a multifaceted review. Current Science, 82 (6) 638-647.

Suratman, M. N. (2012). Tree species diversity and forest stand structure of Pahang National Park, Malaysia. Biodiversity enrichment in a diverse world, 19, 45-56.

Whitmore, T. C. (1998). An introduction to tropical rain forests. $2^{\text {nd }}$ Ed. Oxford: Oxford University Press. 